\title{
Population dynamics and regeneration of Shorea roxburghii, a threatened timber species in Southern region, Viet Nam
}

\author{
TRAN QUANG BAO ${ }^{1,2, \vartheta}$, LE HONG VIET ${ }^{3}$, NGUYEN HONG HAI ${ }^{2}$, NGUYEN THANH TUAN ${ }^{3}$, \\ LE VAN CUONG \\ ${ }^{1}$ Vietnam Administration of Forestry, 2 Ngoc Ha, Ha Noi, Vietnam. Tel.: +84.0945043274, `email: baofuv@ vnuf.edu.vn \\ ${ }^{2}$ Vietnam National University of Forestry, Xuan Mai Town, Ha Noi, Vietnam \\ ${ }^{3}$ Vietnam National University of Forestry - Southern Campus, Trang Bom Town, Dong Nai, Vietnam
}

Manuscript received: 13 October 2021. Revision accepted: 30 November 2021.

\begin{abstract}
Bao TQ, Viet LH, Hai NH, Tuan NT, Cuong LV. 2021. Population dynamics and regeneration of Shorea roxburghii, a threatened timber species in Southern region, Viet Nam. Biodiversitas 22: 5649-5656. Despite its wide distribution in South and Southeast Asia, Shorea roxburghii G. Don is classified as Vulnerable in the IUCN Red List of Threatened Species due to overexploitation for its valuable timber. This study aims to investigate the population dynamics and regeneration of $S$. roxburghii in southeastern Vietnam, serving for conservation and sustainable development plan. Six plots of 2,500 $\mathrm{m}^{2}$ each $(50 \mathrm{~m} \times 50 \mathrm{~m})$ were established at two forest conditions: i) forest with standing volume $>200 \mathrm{~m}^{3} / \mathrm{ha}$ (SV $\left.>200\right)$, and ii) $<200 \mathrm{~m}^{3} / \mathrm{ha}$ (SV<200); to investigate stems with diameter at breast height $(\mathrm{DBH}) \geq 5 \mathrm{~cm}$ and that $<5 \mathrm{~cm}$. Moisture $(\%), \mathrm{pH}_{\mathrm{H} 2 \mathrm{O}}$ of the topsoil and the occurrence of regenerating $S$. roxburghii were collected from 125 points in the study site. The results indicated that mean stem height, DBH, basal area, and aboveground biomass were significantly higher at the forest stand with SV $>200$ than that at the forest stand with SV $<200$ for the pool of all species. Similar higher figures were found in SV $>200$ for the pool of $S$. roxburghii compared to that in SV $<200$, except mean DBH, which was larger in $\mathrm{SV}<200$. There were missing stems with $\mathrm{DBH}<5 \mathrm{~cm}$ in $\mathrm{SV}<200$, while it was numerous in $\mathrm{SV}>200$ (1,313 stems/ha). DBH/stem distributions in both forest types had an inverted-J shape with a peak at 10-15 cm DBH for the pool of all species, while there was no clear pattern for the pool of $S$. roxburghii in both forest types. Regression analysis indicated that higher total crown area of stems $\geq 23$ tall leads to higher $S$. roxburghii stems, while the higher total crown area of stems $<23$ tall leads to fewer $S$. roxburghii stems with DBH $<5 \mathrm{~cm}$. It is concluded that the total crown area of forest stand plays an important role in the sustainable regeneration of S. roxburghii. Silvicultural treatment should be applied to reduce stand density and crown area of stems $<23 \mathrm{~m}$ tall to enhance sunlight reaching the forest floor for germination, growth, and survival of $S$. roxburghii. The moisture of the topsoil ranging from $60-80 \%$ and the $\mathrm{pH}_{\mathrm{H} 2 \mathrm{O}}$ ranging from $3.8-4.6$ are suitable conditions for natural regeneration of S. roxburghii.
\end{abstract}

Keywords: Forest structure, population dynamics, regeneration, Shorea roxburghii

\section{INTRODUCTION}

Shorea roxburghii $\mathrm{G}$. Don. is a commercially valuable timber species from Dipterocarpaceae family. This species has natural distribution in South and Southeast Asia, including India, Myanmar, Thailand, Malaysia, Cambodia, Laos, Vietnam (Ang et al. 2016; Basyuni et al. 2019; Maimunah et al. 2019; Tamilselvan et al. 2021). This species is predominantly found in evergreen, deciduous forests, and even bamboo forests (Le et al. 2020). S. roxburghii is a semi-deciduous tree that can grow up to 40 $\mathrm{m}$ tall at maturity. The species has an economic significance as it is used as valuable commercial timber and as 'white meranti' in many countries of the Southeastern Asia region (Anonymous 1985). For example, it is used for building materials (Pande 2008), local medicines (Morikawa et al. 2012; Subramanian et al. 2013), methanol extract (Morikawa et al. 2012). Besides, thirteen stilbenoids and bioactive constituents were isolated from $S$. roxburghii (Moriyama et al. 2016; Ninomiya et al. 2017).
Because of highly commercial timber and medicinal values, natural populations of $S$. roxburghii had reduced remarkably, leading to Vulnerable status by IUCN (Pooma et al. 2014). This situation is worsened since as Dipterocarps, $S$. roxburghii is not flowering annually (i.e. mast flowering and fruiting phenomenon), while it has annual leaf shedding. Once they are fruiting, healthy seeds germinate as soon as they reach the forest floor (Raju et al. 2011), suggesting that their seeds are recalcitrant. Therefore, soil moisture and canopy openness significantly affect the seedlings' growth, survival, and density (Islam et al. 2016). In this regard, understanding the autecology and population dynamics of $S$. roxburghii is essential for conservation purposes and sustainable management plans.

Sustainable forest management is a major factor in maintaining forest biodiversity (Khuc et al. 2018; Paillet et al. 2010) and population dynamics (Hai et al. 2020; Tran et al. 2011). Population dynamics of any timber species (Tran et al. 2019b; Tran et al. 2010) are represented by three stem layers of seedlings (height $\leq 2 \mathrm{~m}$ ), saplings (diameter at breast height/DBH $<5 \mathrm{~cm}$, and height $>2 \mathrm{~m}$ ), and trees $(\mathrm{DBH} \geq 5 \mathrm{~cm})$. The balance of individuals among three groups in reducing the order of seedlings $>$ saplings $>$ trees 
ensures the sustainable development of the species (Tran et al. 2019b; Tripathi et al. 2007). Meanwhile, stand structure plays a central role in the survival and growth of seedlings and saplings (Tran et al. 2016). Enhancing regeneration of the dominant tree species is a primal condition for sustainable natural forest management (Tran et al. 2016). The establishment, survival, and growth in the natural forest differ among species, depending on its ecological characteristics (Swaine and Whitmore 1988) as plants are categorized as pioneer/light-demanding group, shadetolerant group, and shade-intolerant group. Thus, understanding the population dynamics and regeneration of $S$. roxburghii is necessary to conserve this species in South Vietnam evergreen forests. Two main questions will be addressed: i) How are the population structure, regeneration characteristics and aboveground biomass of stems of $S$. roxburghi $i$ at two conditions with different standing volumes (i.e. $>200 \mathrm{~m}^{3} /$ ha (stable forest) versus $<200$ $\mathrm{m}^{3} / \mathrm{ha}$ ) (unstable forest)? i i) How do the main ecological factors affect the occurrence probability of $S$. roxburghii regeneration?

\section{MATERIALS AND METHODS}

\section{Study area}

Field experiments were conducted in Tan Phu Protection Forest, Dong Nai Province, Southeastern region,

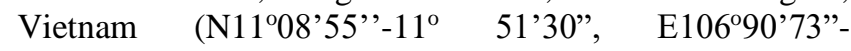
$\left.107^{\circ} 23^{\prime} 74^{\prime \prime}\right)$ (Fig. 1). The study area has a tropical monsoon climate when the rainy season usually occurs on May to November and the dry season occurs from December to April. The mean annual temperature is $25^{\circ} \mathrm{C}$ $\left(21.9^{\circ} \mathrm{C}\right.$ in December and $35.1^{\circ} \mathrm{C}$ in April, respectively), and the average annual precipitation is $2100 \mathrm{~mm}$ (most rainfall occurs from June to October). Annual mean humidity is $80 \%$, and annual average total sunshine time is 2500-2700 hours. The soil type is grey, developed on granite rocks, and has a soil depth of over $100 \mathrm{~cm}$. The is sandy loam in texture with $\mathrm{pH}\left(\mathrm{H}_{2} \mathrm{O}\right)$ of 3.8-4.6 (Tran et al. 2019a). The vegetation in the study site is predominated by evergreen broadleaved forests on a lower slope (below 120 $\mathrm{m}$ elevation). Most forests in the research region have experienced anthropogenic disturbances by selective logging, leading to the current status of secondary forests.

\section{Data collection}

Forests in the study site were classified into two conditions based on standing volume, namely: 1) standing volume $>200 \mathrm{~m}^{3} /$ ha named as SV>200; and 2) standing volume $<200 \mathrm{~m}^{3} /$ ha named as $\mathrm{SV}<200$. In each forest condition, main representative plots (four in SV>200 and two in $\mathrm{SV}<200)$ of $2,500 \mathrm{~m}^{2}(50 \mathrm{~m} \times 50 \mathrm{~m})$ were established. In each main plot, five sub-plots of $16 \mathrm{~m}^{2}(4 \mathrm{~m}$ $\times 4 \mathrm{~m}$ ) were further set in four corners and the central.

In the main plots, all stems with $\mathrm{DBH} \geq 5 \mathrm{~cm}$ were identified to species and measured for $\mathrm{DBH}(\mathrm{cm})$, stem height $(\mathrm{m})$, and crown diameter (CR:m). These stems were known as the tree group. In the sub-plots, all stems with $\mathrm{DBH}<5 \mathrm{~cm}$ were identified to species and measured for stem height, known as an adjacent group.

Moisture $(\%)$ and $\mathrm{pH}_{\mathrm{H} 2 \mathrm{O}}$ of the topsoil $(0-30 \mathrm{~cm})$ were determined by a Soil Integrated Sensor (Soil pH \& Moisture Tester, Model DM-15) at 125 random sites $1 \mathrm{~m}^{2}$ $(1 \mathrm{~m} \times 1 \mathrm{~m})$ in the study area. At each site, we identified the occurrence of $S$. roxburghii regeneration (presence as 1; absence as 0). All Shorea roxburghii trees with $\mathrm{DBH} \leq 5$ $\mathrm{cm}$ were divided into two height classes $\left(\mathrm{H}_{1} \leq 100 \mathrm{~cm} ; \mathrm{H}_{2}\right.$ $>100 \mathrm{~cm}$ ). 


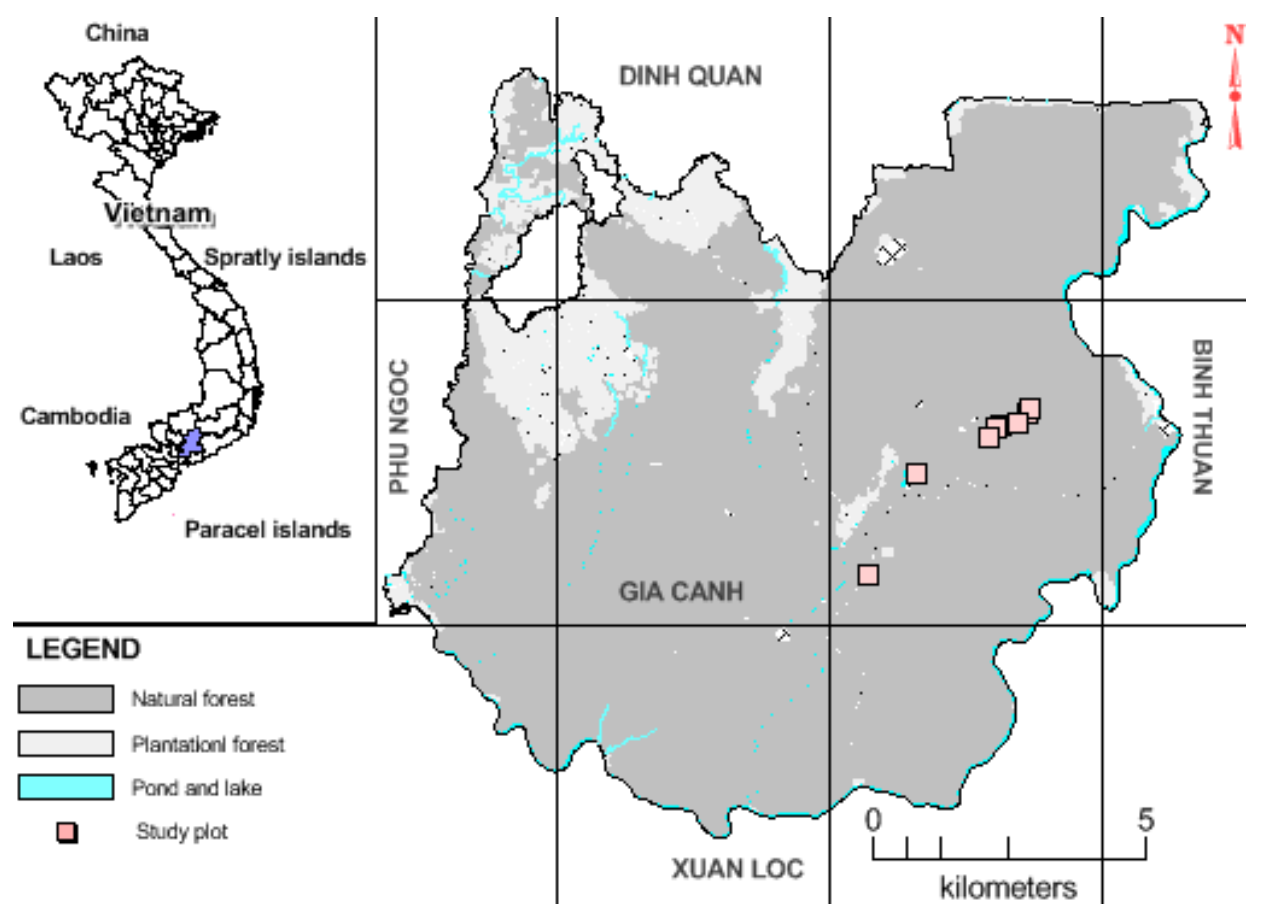

Figure 1. Map of experimental plots in Tan Phu protection forest, Dong Nai, South Vietnam

\section{Data analysis}

Stem basal area $(\mathrm{G})$, crown area $(C A)$, and aboveground biomass $(A G B)$, and standing volume $(S V)$ were estimated for each stem separately. The $G, C A, A G B$, and $S V$ were defined as in the following equation (Hinh 2012; Huy et al. 2016):

$$
\begin{aligned}
& C A=\frac{3.14 x C R^{2}}{4} \\
& A G B=0.12843 \times D B H^{2.409074} \\
& S V=G \times H \times 0.42
\end{aligned}
$$

where: $\mathrm{CR}$, crown diameter (m); $G$, stem basal area $\left(\mathrm{m}^{2}\right) ; D B H$, diameter at breast height $(\mathrm{cm}) ; C A$, crown area $\left(\mathrm{m}^{2}\right) ; A G B$, aboveground biomass $(\mathrm{Mg}) ; S V$, standing volume $\left(\mathrm{m}^{3}\right) ; H$, stem height (m).

The parameters about density, basal area and Importance Value Index (IVI\%) were calculated as below: $\mathrm{ha}^{-1}$ )

Density $(\mathrm{d})=$ number of trees $\left(\mathrm{n}_{\mathrm{i}}\right)$ per unit area (trees.

Where, $n_{i}=$ total individual trees calculated for species $\mathrm{i}$.

Basal area $(\mathrm{G})=\pi \times \mathrm{r}^{2}==\pi \times \frac{d \mathrm{dh}^{2}}{4}\left(\mathrm{~m}^{2}\right)$

Where: $\mathrm{dbh}=$ diameter at breast height and $\mathrm{r}=$ radius.

IVI $(\%)=($ Relative density + Relative Basal area + Relative volume) $/ 3$

Relative basal area and volume were the total basal area (G) and volume (SV) of species i as a percent of all species.

Spearman's rank correlation coefficient was used to separately test correlations between CA and stem density for each forest type. Besides, we used the nonparametric
Mann-Whitney U-test to compare the stand parameters between two forest types.

Gaussian logit regression was used to model the occurrence probability of $S$. roxburghii regeneration in each forest condition corresponding to topsoil moisture $\left(\mathrm{X}_{1}\right)$ and $\mathrm{pH}_{\mathrm{H} 2 \mathrm{O}}\left(\mathrm{X}_{2}\right)$. A quadratic term in logistic regression is being used because species occurrence probabilities often do not show monotonic patterns and have a modal peak (Krishnadas et al. 2021).

$$
\operatorname{Logit}(\mathrm{P} / 1-\mathrm{P})=\mathrm{b}_{0}+\mathrm{b}_{1} * \mathrm{X}_{\mathrm{i}}-\mathrm{b}_{2} * \mathrm{X}_{\mathrm{i}}^{2}
$$

Where $\mathrm{P}=$ occurrence probability of the $S$. roxburghii regeneration for two hight classes $\left(\mathrm{H}_{1} \leq 100 \mathrm{~cm} ; \mathrm{H}_{2}>100\right.$ $\mathrm{cm}), X_{i}=X_{1}$ and $X_{2}$

Then analyze function (7) to determine ecological parameters such as ecological optimum $\left(\mathrm{U}_{\mathrm{i}}\right)$, ecological tolerance $\left(T_{i}\right)$, ecological range $\left(U_{i} \pm 4 T_{i}\right)$ and $P_{i M a x}$ (with $i$ $=1-2$, two hight classes). Four parameters $\mathrm{U}_{\mathrm{i}}, \mathrm{T}_{\mathrm{i}}, \mathrm{U}_{\mathrm{i}} \pm 4 \mathrm{~T}$ and $\mathrm{P}_{\mathrm{iMax}}$ are determined by function (8)-(11). The combined effect of two variables $\mathrm{X}_{1}$ and $\mathrm{X}_{2}$ on the natural regeneration of $S$. roxburghii was analyzed by multivariable Gaussian logit regression (function 12).

Ecological optimum $U_{i}=b_{1} / 2 b_{2}$

Ecological tolerance $T_{i}=1 / \sqrt{ } 2 b_{2}$

Ecological range $\mathrm{U}_{\mathrm{i}} \pm 4 \mathrm{~T}_{\mathrm{i}}$

$$
P_{\text {iMax }}=\frac{\exp \left(b_{0}+b_{1} U_{i}-b_{2} U_{i}^{2}\right)}{1+\exp \left(b_{0}+b_{1} U_{i}-b_{2} U_{i}^{2}\right)}
$$

$$
\operatorname{Logit}(\mathrm{P} / 1-\mathrm{P})=\mathrm{b}_{0}+\mathrm{b}_{1} \mathrm{X}_{1}-\mathrm{b}_{2} \mathrm{X}_{1}^{2}+\mathrm{b}_{3} \mathrm{X}_{2}-\mathrm{b}_{4} \mathrm{X}_{2}^{2}+
$$
$\mathrm{b}_{5} \mathrm{X}_{1} \mathrm{X}_{2}$

All statistical analyses, based on a significant level of $p<0.05$, were conducted using SAS 9.2 (SAS Institute Inc., 
Cary, NC, USA) and SPSS 22.0 (IBM Corp., NY, USA) software packages.

\section{RESULTS AND DISCUSSION}

\section{Population dynamics of Shorea roxburghii}

A total of 92 tree species was recorded in the habitat of S. roxburghii in Tan Phu protection forest. The species richness in stable and the unstable forests was 64 species and 61 species, respectively (Tables 1 and 2).

Table 1. The top ten species having the highest Importance Value Index (IVI) of the forest with standing volume $>200 \mathrm{~m}^{3} \mathrm{ha}^{-1}$

\begin{tabular}{|c|c|c|c|c|c|c|c|}
\hline \multirow[b]{2}{*}{ Species } & \multirow{2}{*}{$\begin{array}{c}\text { Density } \\
\text { (trees) }\end{array}$} & \multirow{2}{*}{$\begin{array}{l}\text { Basal area } \\
\quad\left(\mathbf{m}^{2}\right)\end{array}$} & \multirow{2}{*}{$\begin{array}{c}\text { Volume } \\
\left(\mathbf{m}^{3}\right)\end{array}$} & \multicolumn{4}{|c|}{ Percent $(\%)$} \\
\hline & & & & $\begin{array}{c}\text { Relative } \\
\text { density }\end{array}$ & $\begin{array}{c}\text { Relative } \\
\text { basal area }\end{array}$ & $\begin{array}{l}\text { Relative } \\
\text { volume }\end{array}$ & IVI \\
\hline Shorea roxburghii G. Don & 177 & 8.4 & 76.16 & 26.9 & 30.1 & 30.7 & 29.2 \\
\hline Parinari anamensis Hance & 31 & 3.38 & 32.86 & 4.7 & 12.1 & 13.2 & 10 \\
\hline Syzygium zeylanicum (L.) DC. & 50 & 2.57 & 23.21 & 7.6 & 9.2 & 9.3 & 8.7 \\
\hline Vatica odorata (Griff.) Symington & 38 & 1.5 & 14.63 & 5.8 & 5.4 & 5.9 & 5.7 \\
\hline Irvingia malayana Oliv. ex A.W.Benn. & 11 & 1.23 & 13.06 & 1.8 & 4.4 & 5.3 & 4 \\
\hline Anisoptera costata Korth. & 14 & 1.19 & 11.49 & 2.1 & 4.3 & 4.6 & 3.7 \\
\hline Knema globularia (Lam.) Warb. & 31 & 0.95 & 7.24 & 4.7 & 3.4 & 2.9 & 3.7 \\
\hline Dalbergia cochinchinensis Pierre & 25 & 0.85 & 6.74 & 3.8 & 3 & 2.7 & 3.2 \\
\hline Grewia tomentosa Juss. & 20 & 0.48 & 3.75 & 3 & 1.7 & 1.5 & 2.1 \\
\hline Xylopia vielana Pierre & 21 & 0.45 & 3.42 & 3.2 & 1.6 & 1.4 & 2.1 \\
\hline Total of 10 species & 418 & 21 & 192.56 & 63.6 & 75.2 & 77.5 & 72.4 \\
\hline Others (54 species) & 241 & 6.9 & 55.7 & 36.4 & 24.8 & 22.5 & 27.6 \\
\hline All & 659 & 27.9 & 248.3 & 100 & 100 & 100 & 100 \\
\hline
\end{tabular}

Table 2. The top ten species having the highest Importance Value Index (IVI) of the forest with standing volume $<200 \mathrm{~m}^{3}$ ha-1

\begin{tabular}{|c|c|c|c|c|c|c|c|}
\hline \multirow[b]{2}{*}{ Species } & \multirow[b]{2}{*}{$\begin{array}{c}\text { Density } \\
\text { (trees) }\end{array}$} & \multirow[b]{2}{*}{$\begin{array}{c}\text { Basal area } \\
\left(\mathbf{m}^{2}\right)\end{array}$} & \multirow[b]{2}{*}{$\begin{array}{c}\text { Volume } \\
\left(\mathbf{m}^{\mathbf{3}}\right)\end{array}$} & \multicolumn{4}{|c|}{ Percent (\%) } \\
\hline & & & & $\begin{array}{c}\text { Relative } \\
\text { density }\end{array}$ & $\begin{array}{c}\text { Relative } \\
\text { basal area }\end{array}$ & $\begin{array}{c}\text { Relative } \\
\text { volume }\end{array}$ & IVI \\
\hline Shorea roxburghii G. Don & 143 & 6.31 & 56.55 & 17.9 & 30.2 & 32.3 & 26.8 \\
\hline Syzygium zeylanicum (L.) DC. & 130 & 2.65 & 21.69 & 16.3 & 12.7 & 12.4 & 13.8 \\
\hline Anisoptera costata Korth. & 45 & 1.94 & 17.25 & 5.6 & 9.3 & 9.8 & 8.3 \\
\hline Parinari anamensis Hance & 27 & 1 & 8.83 & 3.4 & 4.8 & 5 & 4.4 \\
\hline Vatica odorata (Griff.) Symington & 47 & 0.62 & 4 & 6 & 3.1 & 2.8 & 4 \\
\hline Diospyros lanceifolia Roxb & 48 & 0.42 & 2.34 & 6 & 2 & 1.3 & 3.1 \\
\hline Goniothalamus gabriacianus (Baill.) & 25 & 0.58 & 4.12 & 3.1 & 2.8 & 2.4 & 2.8 \\
\hline Lophopetalum wightianum Arn. & 25 & 0.5 & 3.77 & 3.1 & 2.4 & 2.2 & 2.6 \\
\hline Xylopia vielana Pierre & 19 & 0.55 & 4.61 & 2.4 & 2.6 & 2.6 & 2.5 \\
\hline Calophyllum calaba $\mathrm{L}$. & 11 & 0.51 & 4.67 & 1.4 & 2.4 & 2.7 & 2.2 \\
\hline Total of 10 species & 520 & 15.08 & 127.83 & 65.2 & 72.3 & 73.5 & 70.5 \\
\hline Others (51 species) & 279 & 5.88 & 47.32 & 34.8 & 27.7 & 26.5 & 29.5 \\
\hline All & 799 & 20.96 & 175.15 & 100 & 100 & 100 & 100 \\
\hline
\end{tabular}

Based on the IVI obtained, Shorea roxburghii had the highest IVI $(29.2 \%)$ followed by the Parinari anamensis $(10 \%)$, Syzygium zeylanicum $(8.7 \%)$. Vatica odorata $((5 \%)$ in stable forest (Table 1). At unstable forest, Shorea roxburghii had the highest IVI $(26.8 \%)$ followed by Syzygium zeylanicum (13.8\%) and Anisoptera costata $(8.3 \%)$ (Table 2). Tree density in the stable forest was lower (659 trees $\mathrm{ha}^{-1}$ ) than that in the unstable forest (789 trees ha-1).

For the pool of all species, the number of species, stems, and total $C A$ at a $2500 \mathrm{~m}^{2}$ plot were not different between the the two forest sites (Table 3). However, the differences of other parameters including mean $H, D B H, G$, $S V$, and $A G B$ were significantly different, indicating the higher figures in the stand with $>200 \mathrm{~m}^{3} / \mathrm{ha}$ standing volume $(S V>200)$ compared to stand with $<200 \mathrm{~m}^{3} / \mathrm{ha}$ standing volume $(S V<200)$.
For the pool of $S$. roxburghii, the mean $H$ was not different between two forest sites (Table 3). While the differences between two forest sites in stem density, mean $D B H, G, S V, A G B$ and total $C A$ were statistically significant. Mean $D B H$ was larger in $S V<200(38 \mathrm{~cm})$ compared to that in $S V>200(27.1 \mathrm{~cm})$. While other parameters were higher in $S V>200$ compared to that in $S V<200$. S. roxburghii stems with $D B H<5 \mathrm{~cm}$ were not found in $S V<200$, while that were 1313 stems/ha in $S V>200$.

For the pool of all species, $66.4 \%$ stems belonged to height classes of $9-19 \mathrm{~m}$ in $S V>200$ (Fig. 2a), and $76.7 \%$ stems belonged to height classes of $9-17 \mathrm{~m}$ in $S V<200$ (Fig. 2b). While $62.9 \% C A$ belonged to height classes of $17-27$ $\mathrm{m}$ in $S V>200$, and $67.7 \% C A$ belonged to height classes of 9-21 $\mathrm{m}$ in $S V<200$. 
For the pool of $S$. roxburghii, stems $<5 \mathrm{~m}$ height were not found and $77.1 \%$ stems belonged to height classes of 9$21 \mathrm{~m}$ in $S V<200$ (Fig. 2g), while $90.1 \%$ stems belonged to height classes of $<5 \mathrm{~m}$ in $S V>200$ (Fig. 2e). In both forest conditions, more than $80 \%$ of the $C A$ belonged to height classes of $>13 \mathrm{~m}$ (Fig. 2f, h).

Both forest conditions had $\mathrm{DBH} /$ stem distributions of inverted-J shape by the reduction of stems in larger DBH with a peak at $10-15 \mathrm{~cm} \mathrm{DBH} \mathrm{(Fig.} \mathrm{3a,} \mathrm{b)} \mathrm{for} \mathrm{the} \mathrm{pool} \mathrm{of} \mathrm{all}$ species. At the same time, there were no clear patterns of $\mathrm{DBH} /$ stem distribution for the pool of $S$. roxburghii (Fig. $3 c, d)$. The stems appeared in all DBH classes in SV>200 (Fig. 3c), while in $\mathrm{SV}<200$ (Fig. 2d), there were missing stems in DBH classes of $25-30 \mathrm{~cm}$ and $50-65 \mathrm{~cm}$.

Regressions between the stand total crown area and stems of $S$. roxburghii $(D B H<5 \mathrm{~cm})$ existed (Fig. 4). Negative linear was best fitted for the relationship between stand total $C A$ of $<23 \mathrm{~m}$ tall stems and stems of $S$. roxburghii (Fig. 4a), while positive linear was best fit for the relationship between stand total $C A$ of $>23 \mathrm{~m}$ tall stems and stems of $S$. roxburghii (Fig. 4b).

Table 3. Comparison of stand parameters $( \pm \mathrm{SE})$ between two forest conditions with different standing volume

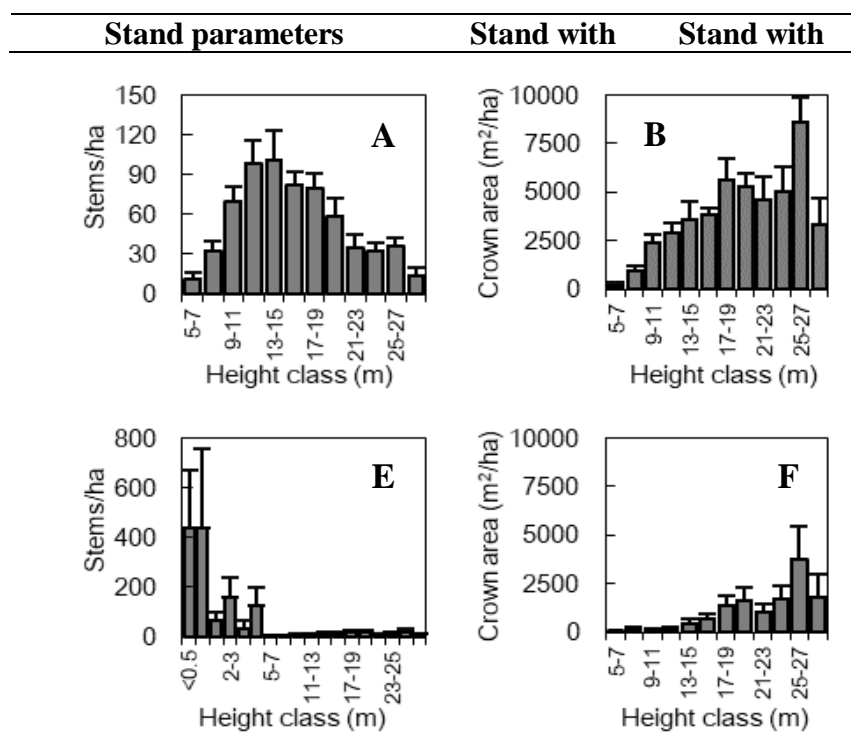

\begin{tabular}{lll}
\hline & $\begin{array}{c}\text { standing volume } \\
\mathbf{> 2 0 0} \mathbf{~ m}^{\mathbf{3}} / \mathbf{h a}\end{array}$ & $\begin{array}{c}\text { standing } \\
\text { volume }<\mathbf{2 0 0} \\
\mathbf{~ m}^{\mathbf{3}} / \mathbf{h a}\end{array}$ \\
\hline A pool of all species & & \\
$\quad$ Species number/2,500 $\mathrm{m}^{2}$ & $38 \pm 4$ & $36 \pm 4$ \\
Stems $/ 2,500 \mathrm{~m}^{2}$ & $161 \pm 8$ & $188 \pm 36$ \\
Mean height $(\mathrm{m})$ & $15.6 \pm 0.5^{\mathrm{a}}$ & $11.9 \pm 0.5^{\mathrm{b}}$ \\
Mean DBH $(\mathrm{cm})$ & $20.9 \pm 0.9^{\mathrm{a}}$ & $16.1 \pm 0.2^{\mathrm{b}}$ \\
Basal area $\left(\mathrm{m}^{2} / 2,500 \mathrm{~m}^{2}\right)$ & $8.1 \pm 0.6^{\mathrm{a}}$ & $5.6 \pm 0.6^{\mathrm{b}}$ \\
Standing volume $\left(\mathrm{m}^{3} / 2,500 \mathrm{~m}^{2}\right)$ & $72.8 \pm 7.2^{\mathrm{a}}$ & $39.2 \pm 4.6^{\mathrm{b}}$ \\
Aboveground biomass $\left(\mathrm{Mg} / 2,500 \mathrm{~m}^{2}\right)$ & $59.9 \pm 5.0^{\mathrm{a}}$ & $38.4 \pm 1.7^{\mathrm{b}}$ \\
Crown area $\left(\mathrm{m}^{2} / 2,500 \mathrm{~m}^{2}\right)$ & $11,569 \pm 602$ & $9,284 \pm 1,374$
\end{tabular}

\section{Pool of Shorea roxburghii}

Stems with $\mathrm{DBH} \geq 5 \mathrm{~cm}$

$\begin{array}{lll}\text { Stems } / 2,500 \mathrm{~m}^{2} & 34 \pm 5^{\mathrm{a}} & 17 \pm 13^{\mathrm{b}} \\ \text { Mean height }(\mathrm{m}) & 17.9 \pm 1.6 & 17.7 \pm 3.1 \\ \text { Mean DBH }(\mathrm{cm}) & 27.1 \pm 3.6^{\mathrm{a}} & 38.0 \pm 16.4^{\mathrm{b}} \\ \text { Basal area }\left(\mathrm{m}^{2} / 2,500 \mathrm{~m}^{2}\right) & 2.7 \pm 0.9^{\mathrm{a}} & 1.3 \pm 0.3^{\mathrm{b}} \\ \text { Standing volume }\left(\mathrm{m}^{3} / 2,500 \mathrm{~m}^{2}\right) & 26.6 \pm 9.4^{\mathrm{a}} & 11.4 \pm 2.5^{\mathrm{b}} \\ \text { Biomass }\left(\mathrm{Mg} / 2,500 \mathrm{~m}^{2}\right) & 20.7 \pm 7.0^{\mathrm{a}} & 10.4 \pm 1.8^{\mathrm{b}} \\ \text { Crown area }\left(\mathrm{m}^{2} / 2,500 \mathrm{~m}^{2}\right) & 3,230 \pm 778^{\mathrm{a}} & 1,273 \pm 603^{\mathrm{b}} \\ \text { Stems with } \mathrm{DBH}<5 \mathrm{~cm} & & \end{array}$

Stems with $\mathrm{DBH}<5 \mathrm{~cm}$

Stems/ha $1,313 \pm 277^{\mathrm{a}} \quad 0^{\mathrm{b}}$

Note: Different letters ${ }^{\mathrm{a}, \mathrm{b}}$ in a line indicates a significant means difference between two forest sites at $\mathrm{p}$ : $0.05 ; \mathrm{H}$ : stem height; DBH: diameter at breast height; G: basal stem area; SV: standing volume; AGB: aboveground biomass; CA: crown area
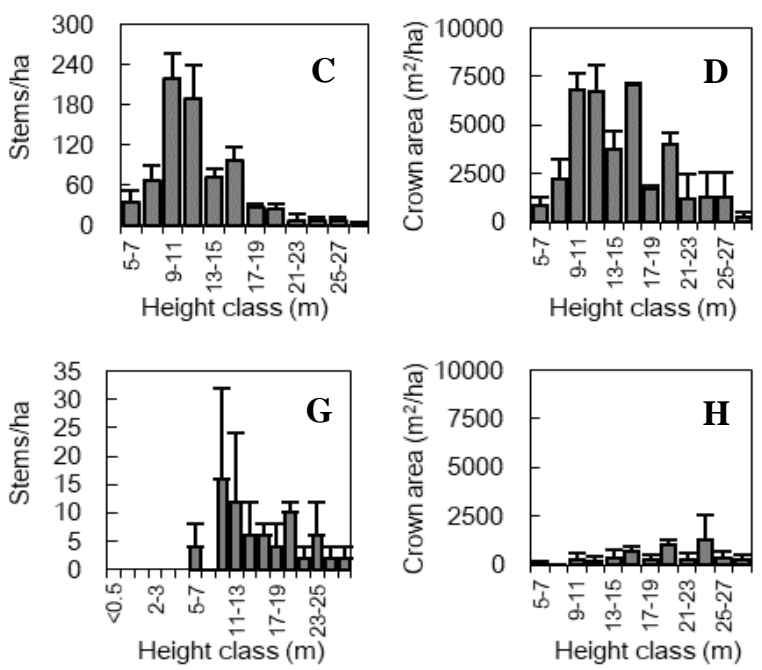

Figure 2. (A, B, E, F) Height/stem and height/crown area distributions in the forest with standing volume $>200 \mathrm{~m}^{3} \mathrm{ha}^{-1} \mathrm{and}(\mathrm{C}, \mathrm{D}, \mathrm{G}$, H) stand with standing volume $<200 \mathrm{~m}^{3} \mathrm{ha}^{-1}$ (A, B, C, D) for the pool of all species and (E, F, G, H) the pool of Shorea roxburghii. Error bars show the standard deviation (SD) 

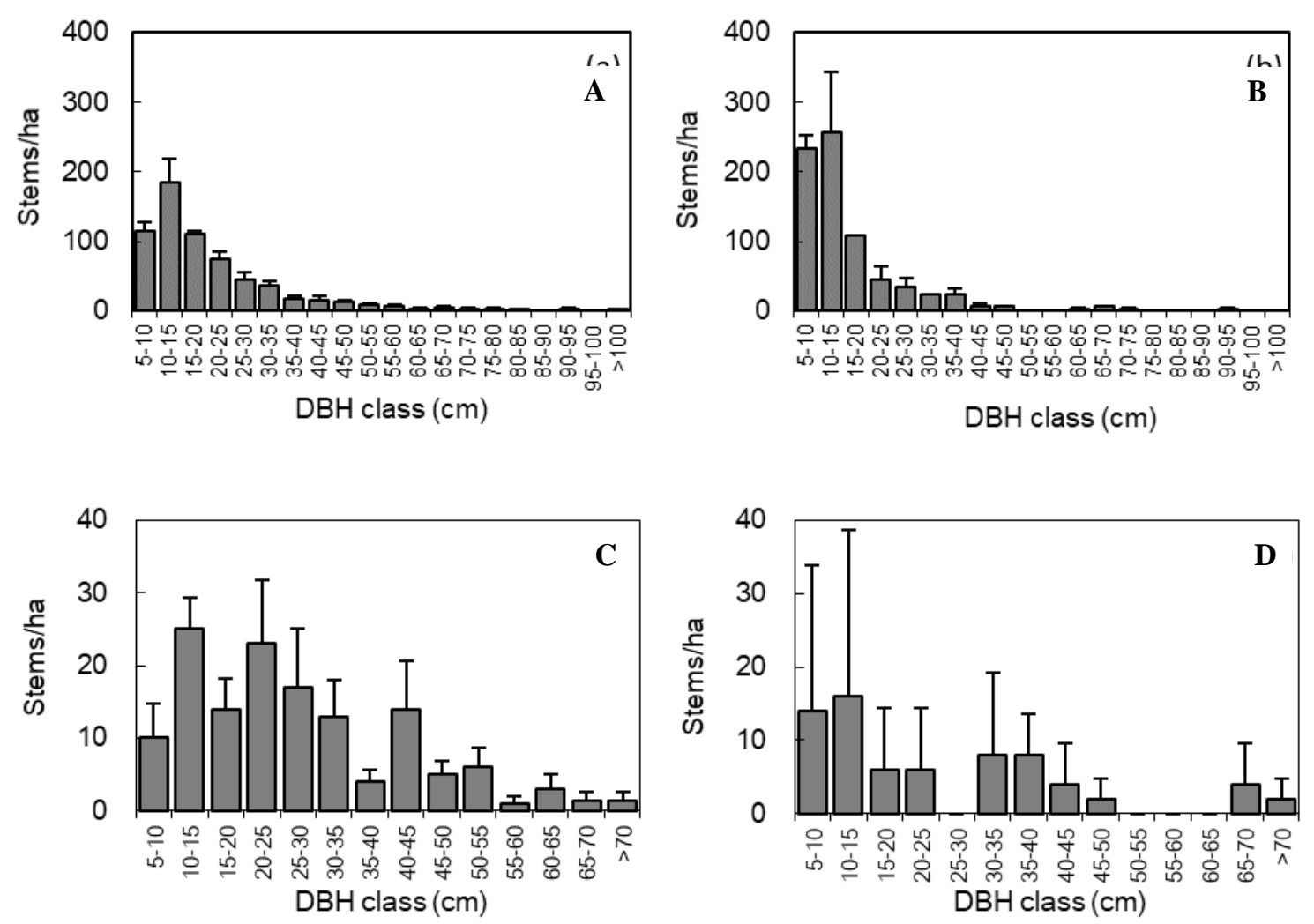

Figure 3. (A, C) DBH/stem distribution at the forest stand with standing volume $>200 \mathrm{~m}^{3} \mathrm{ha}^{-1}$ and (B, D) forest stand with standing volume $<200 \mathrm{~m}^{3} \mathrm{ha}^{-1}(\mathrm{a}, \mathrm{b})$ for the pool of all species and (c, d) the pool of Shorea roxburghii. Error bars show the standard deviation (SD)
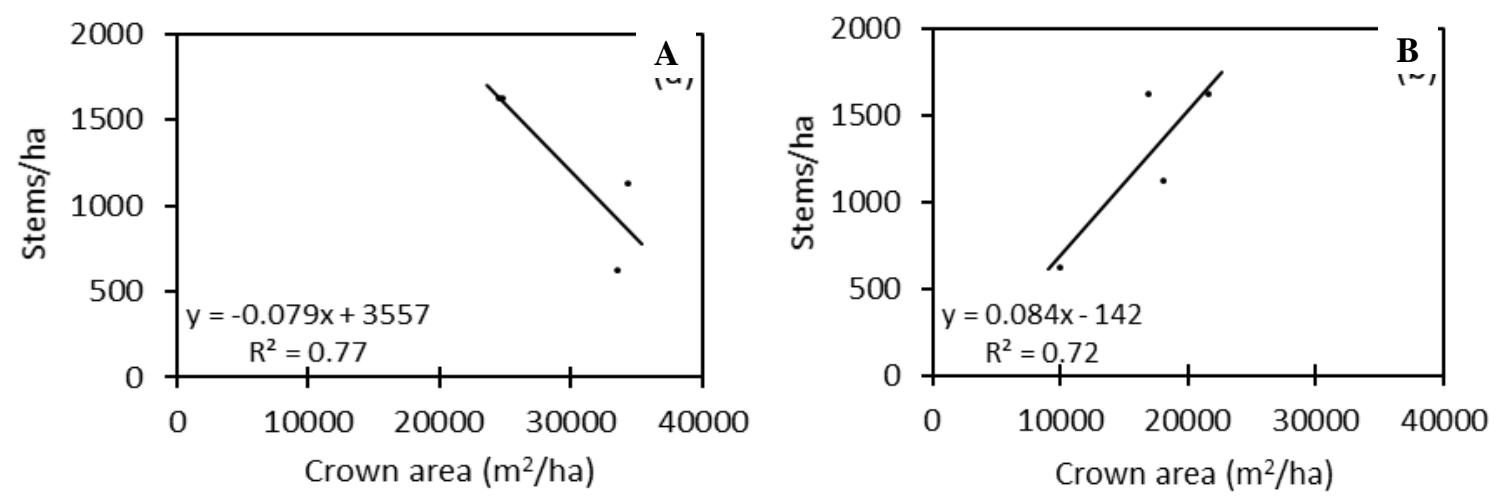

Figure 4. Linear regression between Shorea roxburghii stems (DBH $<5 \mathrm{~cm}$ ) and stand CA of all $<23 \mathrm{~m}$ tall stems (A), and between $S$. roxburghii stems $(\mathrm{DBH}<5 \mathrm{~cm})$ and stand crown area of all $\geq 23 \mathrm{~m}$ tall stems (B)

\section{The occurrence probability of Shorea roxburghii regeneration}

Statistical analyzes showed that the occurrence probability of $S$. roxburghii regeneration $\left(\mathrm{P}_{\mathrm{X}}\right)$ at 2 hight classes $(\mathrm{H}<100 \mathrm{~cm} ; \mathrm{H}>100 \mathrm{~cm})$ and 2 topsoil factors $\left(\mathrm{X}_{1}\right.$ $=$ moisture \%), $\left.\mathrm{X}_{2}=\mathrm{pH}_{\mathrm{H} 2 \mathrm{O}}\right)$ had significant effects with $\mathrm{r}^{2}$ $=17.2-28.1 \%$ and $\mathrm{P}<0.001$ (Tables 4 and 5$)$.
The ecological parameters for topsoil moisture and $\mathrm{pH}_{\mathrm{H} 2 \mathrm{O}}$ (ecological optimum, range and tolerance) for natural regeneration of the $S$. roxburghii population were calculated using equations (13-18) (Tables 5). The regeneration of $S$. roxburghii at the $\mathrm{H}<100 \mathrm{~cm}$ and $\mathrm{H}>$ $100 \mathrm{~cm}$ have similar moisture and $\mathrm{pH}_{\mathrm{H} 2 \mathrm{O}}$ requirements in the topsoil. In both height classes, the optimum topsoil 
moisture requirement is $70.0 \%$ with an ecological range of $61-80 \%$ and tolerance range of $32-100 \%$. The optimum $\mathrm{pH}_{\mathrm{H} 2 \mathrm{O}}$ requirement is 4.0 with an ecological range of 3.84.6 and tolerance range 2.6-5.9.

The combined effect of topsoil moisture and $\mathrm{pH}_{\mathrm{H} 2 \mathrm{O}}$ on the natural regeneration of $S$. roxburghii was analyzed by multivariable Gaussian logit regression.

Statistical analysis shows that the combination of two factors $\left(\mathrm{X}_{1}=\right.$ moisture and $\left.\mathrm{X}_{2}=\mathrm{pH}_{\mathrm{H} 2 \mathrm{O}}\right)$ affects the occurrence probability of $S$. roxburghii regeneration. Three multivariable Gaussian logit regression models (Table 6) are statistically significant at $\mathrm{P}<0.001$. The coefficient $\mathrm{b}_{5}$ of the three models are statistically significant at $\mathrm{P}<0.05$, and less than 0 , meaning that there is an inverse relationship between topsoil moisture and $\mathrm{pH}_{\mathrm{H} 2 \mathrm{O}}$ and $S$. roxburghii regeneration. In another word, when topsoil moisture and $\mathrm{pH}_{\mathrm{H} 2 \mathrm{O}}$ increase, the abundance of $S$. roxburghii regeneration decrease, and vice versa.

Table 4. The occurrence probability of $S$. roxburghii regeneration as the effect of topsoil moisture and $\mathrm{pH}$

\begin{tabular}{|c|c|c|c|c|c|c|}
\hline \multirow{2}{*}{ Function } & \multirow{2}{*}{ Hight class (cm) } & \multicolumn{5}{|c|}{ Regression coefficients } \\
\hline & & $\mathbf{b}_{0}$ & $\mathbf{b}_{1}$ & $\mathbf{b}_{2}$ & $\mathbf{r}^{2}(\%)$ & $\overline{\mathbf{P}_{\alpha}}$ \\
\hline \multicolumn{7}{|c|}{ * Effect of topsoil moisture } \\
\hline (13) & $<100$ & $-26,15040$ & 0,82563 & $-0,00593$ & 27,8 & $<0,001$ \\
\hline (14) & $>100$ & $-22,88920$ & 0,72173 & $-0,00514$ & 21,8 & $<0,001$ \\
\hline$(15)$ & All hight & $-23,90340$ & 0,75075 & $-0,00532$ & 22,6 & $<0,001$ \\
\hline \multicolumn{7}{|c|}{ * Effect of topsoil $\mathrm{pH}_{\mathrm{H} 2 \mathrm{O}}$} \\
\hline$(16)$ & $<100$ & $-44,1541$ & 23,3147 & $-2,9098$ & 28,1 & $<0,001$ \\
\hline (17) & $>100$ & $-34,8796$ & 18,4250 & $-2,2833$ & 19,6 & $<0,001$ \\
\hline (18) & All hight & $-49,9936$ & 24,5884 & $-2,9037$ & 17,2 & $<0,001$ \\
\hline
\end{tabular}

Table 5. Ecological optimum, tolerance and range of S. roxburghii regeneration at two height classes

\begin{tabular}{|c|c|c|c|c|c|c|}
\hline \multirow{2}{*}{ Functions } & \multirow{2}{*}{$\begin{array}{l}\text { Height class } \\
\text { (cm) }\end{array}$} & \multicolumn{5}{|c|}{ Parameters $^{(*)}$ : } \\
\hline & & $\mathbf{U}$ & $\pm T$ & $\mathbf{U} \pm \mathbf{T}$ & $\mathrm{U} \pm 4 \mathrm{~T}$ & $\mathbf{P}_{\max }$ \\
\hline \multicolumn{7}{|c|}{ * Topsoil moisture $(\%)$} \\
\hline 19 & $<100$ & 69,7 & 9,2 & $61-79$ & $33-100$ & 0,9312 \\
\hline 20 & $>100$ & 70,2 & 9,9 & $60-80$ & $31-100$ & 0,9210 \\
\hline 21 & All & 70,5 & 9,7 & $61-80$ & $32-100$ & 0,9290 \\
\hline \multicolumn{7}{|l|}{ * Topsoil pHнго } \\
\hline 22 & $<100$ & 4,0 & 0,4 & $3,6-4,4$ & $2,3-5,7$ & 0,9197 \\
\hline 23 & $>100$ & 4,0 & 0,5 & $3,6-4,5$ & $2,2-5,9$ & 0,9027 \\
\hline 24 & All & 4,2 & 0,4 & $3,8-4,6$ & $2,6-5,9$ & 0,8865 \\
\hline
\end{tabular}

Note: $* \mathrm{U}=$ ecological optimum; $\mathrm{U} \pm \mathrm{T}=$ ecological range; $\mathrm{U} \pm 4 \mathrm{~T}=$ ecological tolerance

Table 6. The occurrence probability of $S$. roxburghii regeneration estimation (Chave et al. 2005). The existence of $S$. corresponding to by topsoil moisture and $\mathrm{pH}_{\mathrm{H} 2 \mathrm{O}}$

\begin{tabular}{|c|c|c|c|}
\hline \multirow{2}{*}{$\begin{array}{l}\text { Regression } \\
\text { coefficients }\end{array}$} & \multicolumn{3}{|c|}{ Hight class (m) } \\
\hline & $<100$ & $>100$ & All \\
\hline $\mathrm{b}_{0}$ & $-10,29370$ & 1,21125 & $-6,68005$ \\
\hline $\mathrm{b}_{1}$ & 5,05212 & 6,66595 & 6,33450 \\
\hline $\mathrm{b}_{2}$ & 0,11412 & 0,14333 & 0,13543 \\
\hline$b_{3}$ & $-83,33940$ & $-118,196$ & $-108,549$ \\
\hline $\mathrm{b}_{4}$ & 57,57400 & 75,2791 & 71,0934 \\
\hline $\mathrm{b}_{5}$ & $-5,31272$ & $-6,78114$ & $-6,42935$ \\
\hline $\mathrm{R}^{2}$ & 32,3 & 29,2 & 29,9 \\
\hline $\mathrm{P}_{\alpha}$ (Model) & $<0,001$ & $<0,001$ & $<0,001$ \\
\hline $\begin{array}{l}\mathrm{P}_{\mathrm{b} 5}\left(\mathrm{~b}_{5}\right. \\
\text { coefficient) }\end{array}$ & 0,0427 & 0,0072 & 0,0112 \\
\hline
\end{tabular}
roxburghii in the forest plays an important role in biodiversity and carbon storage against global warming and climate change.

A larger mean DBH of $S$. roxburghii in $\mathrm{SV}<200(38$ $\mathrm{cm})$ compared to that in SV>200 $(27.1 \mathrm{~cm}$; Table 1) was found in the present study. This could be explained by the more numerous stems of different DBH classes, especially in small classes (Fig. 3c) in SV>200. The fewer stems in small DBH classes in $\mathrm{SV}<200$ (Fig. 3d) resulted from missing stems in $<5 \mathrm{~cm}$ DBH (Fig. $2 \mathrm{~g}$ ). Such missing may lead to difficulty for the regeneration and long-term management of $S$. roxburghii in SV $<200$ stands (Paillet et al. 2010). In addition, the missing stems in DBH classes of $50-65 \mathrm{~cm}$ (Fig. 3d) in $\mathrm{SV}<200$ may result from illegal logging, as loggers prefer good quality stems of desirable sizes for their ability to transport timber out of the forest (Tran et al. 2018). Therefore, even stems with $>65 \mathrm{~cm}$ DBH were available, but they are in bad stem form, rotted timber, and low commercial value.

S. roxburghii was one of the trees with the largest DBH and tallest species on the study site. It forms an emergent and main canopy layer in both forest types. The similarity was also found in other forests (Raju et al. 2011; Tran et al. 
2019a). Dey et al. (2021) also mentioned that crown diameter has a profound correlation with tree diameter and height. Stems of different heights from $<5 \mathrm{~m}$ to $28 \mathrm{~m}$ tall were found in SV>200 (Fig. 2e), while the total stand crown area was $>44,000 \mathrm{~m}^{2} /$ ha. This indicated that $S$. roxburghii is shade-intolerant timber species. Such species require shading at some levels in seedling and sapling stages, and the sunlight requirement increases with increasing ages in their life (Maury-Lechon et al. 1998; Tran et al. 2019b).

Large and adult stems of $S$. roxburghii were found in both forest types (Table 1). At the same time, S. roxburghii has winged fruits, which can be dispersed by wind (Raju et al. 2011; Tran et al. 2019a). Therefore, seed rain is available in both forest types. However, small-sized stems of $S$. roxburghii were not found in $\mathrm{SV}<200$. This could be explained by the inability of seed germination from the stem and crown structure (Fig. 2 a, b, c, d). In SV<200, $92.4 \%$ crown area $\left(34,000 \mathrm{~m}^{2} / \mathrm{ha}\right)$ focused on $5-23 \mathrm{~m}$ tall stems, compared to only $63.4 \%\left(29,000 \mathrm{~m}^{2} / \mathrm{ha}\right)$ in $\mathrm{SV}>200$. Crown area in $<23 \mathrm{~m}$ tall stems blocked most sunlight reaching the forest floor, reducing seed germination and causing the immediate death of just-germinated seed in $\mathrm{SV}<200$. The missing small-sized stems of $S$. roxburghii in SV $<200$ may also result from other unknown reasons. Therefore, further searching for such a phenomenon is necessary (Maury-Lechon et al. 1998).

Crown structure in the present study forest was classified into two groups vertically: one with stems of < $23 \mathrm{~m}$ tall and the other with stems of $\geq 23 \mathrm{~m}$ tall. Total crown area and arrangement in each group control sunlight to penetre to the lower layer and then forest floor (Ådjers et al. 1995), affecting natural germination, survival, and growth of seedlings and saplings of all species including $S$.

\section{ACKNOWLEDGEMENT}

We would like to thank Tran Van Do and Phung Dinh Trung from Silviculture Research Institute, Vietnamese Academy of Forest Science for providing insight and expertise that greatly assisted the manuscript preparation.

\section{REFERENCES}

Ådjers G, Hadengganan S, Kuusipalo J, Nuryanto K, Vesa L. 1995 Enrichment planting of dipterocarps in logged-over secondary forests: effect of width, direction and maintenance method of planting line on selected Shorea species. For Ecol Manag 73 (1-3): 259-270. DOI: 10.1016/0378-1127(94)03488-I.

Ang CC, O’brien MJ, Ng KKS, Lee PC, Hector A, Schmid B, Shimizu KK. 2016. Genetic diversity of two tropical tree species of the Dipterocarpaceae following logging and restoration in Borneo: high genetic diversity in plots with high species diversity. Plant Ecol Divers 9 (5-6): 459-469. DOI: 10.1080/17550874.2016.1270363.

Anonymous. 1985. Dipterocarps of South Asia. RAPA Monograph 4/85, FAO Regional Office for the Asia and the Pacific.

Basyuni M, Slamet B, Sulistiyono N, Thoha A, Bimantara Y, Widjaja E. 2019. Species composition and plant diversity of logged-over forest in Sikundur, Gunung Leuser National Park, North Sumatra. IOP Conf roxburghii (Tran et al. 2019b). The effects of these two groups on $S$. roxburghii stems of $<5 \mathrm{~cm} \mathrm{DBH}$ were both negative and positive (Fig. 4). The higher crown area of 5$23 \mathrm{~m}$ tall stems with many layers (Fig. 1b, d) and numerous stems (Fig. 2 a, c) blocked sunlight reaching the forest floor (Tran et al. 2018). Therefore, it reduces the density of $S$. roxburghii stems of $<5 \mathrm{~cm} \mathrm{DBH}$, which are generally $<5$ $\mathrm{m}$ tall. While the higher crown area of $\geq 23 \mathrm{~m}$ tall stems with fewer layers (Fig. 2b, d) and stems (Fig. 2a, c) will not fully block sunlight other than control it to more suitable intensity for small-sized stems in the lower canopy, leading to higher stem density of $S$. roxburghii (Fig. 4b).

To conclude, the present study results indicated the population dynamics and stand structure of $S$. roxburghii in two forest conditions in the Southeastern region, Vietnam. The stem density of $S$. roxburghii was more numerous in the stand with standing volume $>200 \mathrm{~m}^{3} /$ ha than that in the stand with standing volume $<200 \mathrm{~m}^{3} /$ ha. Whereas in the latter one, there were missing small-sized stems $(D B H<5$ $\mathrm{cm}$ stems) and stems in $D B H$ classes of $25-30 \mathrm{~cm}$ and $55-$ $65 \mathrm{~cm}$. Increasing total $C A$ of $\geq 23 \mathrm{~cm}$ tall stems leads to increasing small-sized stems of $S$. roxburghii, but stems will reduce if the total $C A$ of $<23 \mathrm{~m}$ tall stems increases. Topsoil moisture and $\mathrm{pH}_{\mathrm{H} 2 \mathrm{O}}$ effect on occurrence probability and abundance of Shorea roxburghii regeneration. Based on the finding of this study, it is suggested that to sustainably conserve and manage $S$. roxburghii in the Southeastern region of Vietnam and silvicultural practices should be applied by reducing the stand crown area of $<23 \mathrm{~m}$ tall stems. The practices aim to increase sunlight penetrating the canopy and reaching the forest floor for germination, survival, and growth of $S$. roxburghii.

Ser: Earth Environ Sci 374 (1). DOI: 10.1088/17551315/374/1/012051.

Chave J, Andalo C, Brown S, Cairns MA, Chambers JQ, Eamus D, Folster H, Higuchi N, Kira T, Lescure JP, Nelson BW, Ogawa H, Puig H, Riera B, Yamakura T. 2005. Tree allometry and improved estimation of carbon stocks and balance in tropical forests. Oecologia 145 (1): 87-99. DOI: 10.1007/s00442-005-0100-x.

Dey T, Ahmed S, Islam MA. 2021. Relationships of tree height-diameter at breast height $(\mathrm{DBH})$ and crown diameter-DBH of Acacia auriculiformis plantation. Asian J For 5 (2): 71-75. DOI: 10.13057/asianjfor/r050203.

Hai NH, Tan NT, Bao TQ, Petritan AM, Mai TH, Hien CTT, Anh PT, Hung VT, Petritan IC. 2020. Changes in community composition of tropical evergreen forests during succession in Ta Dung National Park, Central Highlands of Vietnam. Forests 11 (12), 1358. DOI: 10.3390/f11121358.

Hinh VT. 2012. Method to Construct of Standing Volumes Table for Natural Forest of Vietnam. Agriculture Publishing House, Hanoi.

Huy B, Kralicek K, Poudel KP, Phuong VT, Van KP, Hung ND, Temesgen H. 2016. Allometric equations for estimating tree aboveground biomass in evergreen broadleaf forests of Viet Nam. For Ecol Manag 382, 193-205. DOI: 10.1016/j.foreco.2016.10.021.

Islam M, Salim SH, Kawsar MH, Rahman M. 2016. The effect of soil moisture content and forest canopy openness on the regeneration of Dipterocarpus turbinatus CF Gaertn. (Dipterocarpaceae) in a protected forest area of Bangladesh. Trop Ecol 57 (3): 455-464.

Khuc VQ, Tran BQ, Meyfroidt P, Paschke MW. 2018. Drivers of deforestation and forest degradation in Vietnam: An exploratory analysis at the national level. For Pol Econ 90: 128-141. DOI: 10.1016/j.forpol.2018.02.004.

Krishnadas M, Sankaran M, Page N, Joshi J, Machado S, Nataraj N, Chengappa SK, Kumar V, Kumar A, Krishnamani R. 2021. Seasonal 
drought regulates species distributions and assembly of tree communities across a tropical wet forest region. Global Eco

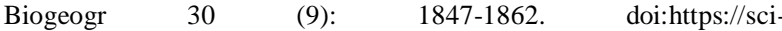
hub.ru/10.1111/geb.13350.

Le HV, Nguyen HH, Tran QB, Nguyen VT, Le NH. 2020. The spatial structural characteristics of dominant species in tropical moist evergreen closed forest at Tan Phu zone, Dong Nai Province. J For Sci Technol 01, 72-82.

Maimunah S, Capilla B, Harrison M. 2019. Tree diversity and fores composition of a Bornean heath forest, Indonesia. IOP Conf Ser: Earth Environ Sci 270 (1). DOI: 10.1088/1755-1315/270/1/012028.

Maury-Lechon G, Curtet L. 1998. Biogeography and evolutionary systematics of Dipterocarpaceae. In: Appanah S, Turnbull JM (eds) A Review of Dipterocarps: Taxonomy, Ecology and Silviculture. Center for International Forestry Research, Indonesia.

Morikawa T, Chaipech S, Matsuda H, Hamao M, Umeda Y, Sato H, Tamura H, Ninomiya K, Yoshikawa M, Pongpiriyadacha Y, Hayakawa T, Muraoka O. 2012. Anti-hyperlipidemic constituents from the bark of Shorea roxburghii. J Nat Med 66 (3): 516-524. DOI: 10.1007/s11418-011-0619-6.

Moriyama H, Moriyama M, Ninomiya K, Morikawa T, Hayakawa T 2016. Inhibitory effects of oligostilbenoids from the bark of Shorea roxburghii on malignant melanoma cell growth: Implications for novel topical anticancer candidates. Biol Pharm Bull 39(10), 1675 1682. DOI: $10.1248 / \mathrm{bpb}$. b16-00420.

Ninomiya K, Chaipech S, Kunikata Y, Yagi R, Pongpiriyadacha Y, Muraoka O, Morikawa T. 2017. Quantitative determination of stilbenoids and dihydroisocoumarins in Shorea roxburghii and evaluation of their hepatoprotective activity. Intl J Mol Sci 18 (2): 451. DOI: 10.3390/ijms18020451.

Paillet Y, Bergès L, Hjältén J, Ódor P, Avon C, Bernhardt-Römermann M, Bijlsma RJ, Fuhr M, Grandin U, Kanka R, Lundin L, Luque S, Magura T, Matesanz S, Meszaros I, Sebastia MT, Schmidt W, Standovar T, Tothmeresz B, Uotila A, Valladares F, Virtanen R. 2010. Biodiversity differences between managed and unmanaged forests: Meta-analysis of species richness in Europe. Conserv Biol 24 (1): 101-112. DOI: 10.1111/j.1523-1739.2009.01399.x.

Pande PK. 2008. Wood density variations in Meranti timbers of Shorea species of Malay Peninsula. J Timber Develop Assoc India 54 (1/4): $10-19$.
Pooma R, Newman M, Barstow M. 2014. Shorea roxburghii. The IUCN red list of threatened species 2017. [17-7-2020]

Raju A, Ramana KV, Chandra PH. 2011. Reproductive ecology of Shorea roxburghii G. Don (Dipterocarpaceae), an Endangered semievergreen species tree of peninsular India. J Threat Taxa 2061-2070. DOI: 10.11609/JoTT.o2763.2061-70.

Subramanian R, Subbramaniyan P, Raj VJS. 2013. Antioxidant activity of the stem bark of Shorea roxburghii and its silver reducing power. SpringerPlus 2 (1): 1-11. DOI: 10.1186/2193-1801-2-28.

Swaine MD, Whitmore T. 1988. On the definition of ecological species groups in tropical rain forests. Vegetatio 75 (1): 81-86. DOI: 10.1007/BF00044629.

Tamilselvan B, Sekar T, Anbarashan M. 2021. Tree diversity, stand structure and community composition of tropical forest in Eastern Ghats of Tamil Nadu, India. J Asia-Pac Biodivers 147 (5): 481-489. DOI: 10.1016/j.japb.2016.03.019.

Tran QB, Le HV. 2019a. Ecological role of Shorea roxburghii population in tree species composition of tropical moist evergreen closed forest in Tan Phu Zone of Dong Nai Province. J For Sci Technol 5, 90-98.

Tran QB, Le HV. 2019b. The effect of ecological factors to natural regeneration of Shorea roxburghii g. don in tropical moist evergreen closed forest at Tan Phu zone of Dong Nai Province. J For Sci 3, 77 88

Tran VD, Cam N, Sato T, Binh N, Kozan O, Thang N, Mitlöhner R. 2016. Post-logging regeneration and growth of commercially valuable tree species in evergreen broadleaf forest, Vietnam. J Trop For Scie 426435.

Tran VD, Kozan O, Yamamoto M, Dai Hai V, Trung PD, Thang NT, Thinh NH. 2018. A natural forest of commercial timber species: logging or not logging. Small-scale For 17 (4): 555-568. DOI: 10.1007/s11842-018-9403-8.

Tran VD, Osawa A, Thang NT. 2010. Recovery process of a mountain forest after shifting cultivation in Northwestern Vietnam. For Ecol Manag 259 (8): 1650-1659. DOI: 10.1016/j.foreco.2010.01.043.

Tran VD, Osawa A, Thang NT, Van NB, Hang BT, Khanh CQ, Tuan DX. 2011. Population changes of early successional forest species after shifting cultivation in Northwestern Vietnam. New For 41 (2): 247262. DOI: $10.1007 / \mathrm{s} 11056-010-9225-9$.

Tripathi R, Khan M. 2007. Regeneration dynamics of natural forests - A review. Proc Indian Nat Sci Acad 73, 167-195. 